\title{
Distribution, status and conservation problems of the Spanish Ibex, Capra pyrenaica (Mammalia: Artiodactyla) $\dagger$
}

\author{
JESÚS M. PÉREZ*, JOSÉ E. GRANADOSł, RAMÓN C. SORIGUER§, \\ PAULINO FANDOSף, FRANCISCO J. MÁRQUEZ* and \\ JEAN P. CRAMPE** \\ *Department of Animal and Plant Biology, and Ecology, Jaén University, Paraje Las \\ Lagunillas, s.n. E-23071 Jaén, Spain, łParque Nacional de Sierra Nevada, Carretera de \\ Pinos Genil, Km. 7. E-18071 Granada, Spain, SEstación Biológica de Doñana (CSIC), \\ Av. María Luisa, s.n. E-41013 Sevilla, Spain, ףAdecuación Ambiental, Almadén 15, \\ $3^{a}$ Pta. 4, E-28014 Madrid, Spain, **Parc National des Pyrénées, 59, Route de Pau, \\ F-65000 Tarbes, France
}

\begin{abstract}
In this paper, the distribution and status of the Spanish Ibex, Capra pyrenaica (Mammalia: Artiodactyla), are revised. The whole Iberian population numbers nearly 50000 , distributed in more than 50 nuclei, and has generally increased during the last decades. Nevertheless, within this wider context, different conditions apply to different populations, including recent extinction (the Pyrenean population), recovery from recent severe epizooty of sarcoptic mange (e.g. the Sierras de Cazorla and Segura y Las Villas range population) and populations at high densities (e.g. Gredos mountain range and Sierra de Grazalema Natural Park, among others). The main factors affecting the conservation of this species are also reported and discussed. On the basis of current information we propose the status of 'vulnerable' for the Spanish Ibex.
\end{abstract}

Keywords: Capra pyrenaica, Ibex, population, Spain

\section{INTRODUCTION}

The genus Capra is naturally distributed throughout the Palaearctic and north-eastern Africa, the Spanish Ibex (Capra pyrenaica Schinz 1838) being one of the six wild species included in this genus (Corbet, 1978; Fandos \& Medem, 1994). This is a medium-sized mountain ungulate showing a marked sexual dimorphism (Schaller, 1977; Fandos, 1991; Granados et al., 1997). Different ibex populations exhibit certain peculiarities regarding body size, horn shape and hair colour pattern, to the point that Cabrera $(1911,1914)$ recognized four $C$. pyrenaica subspecies, whose taxonomic status is still discussed (Couturier, 1962; Clouet, 1979; Shackleton, 1997). Recent genetic studies (Manceau et al., 1999) also question this classification.

About 80000 years ago an ibex close to C. caucasica Guldenstaedt \& Pallas 1783 inhabited the eastern border of the Central Massif, in France, and the Pyrenees. Subsequently, types

Correspondence: Jesús M. Pérez, Department of Animal and Plant Biology, and Ecology, Jaén University, Paraje Las Lagunillas, s.n. E-23071 Jaén, Spain (E-mail: jperez@ujaen.es).

†Our friend and colleague Dr I. Ruiz-Martínez died in July 1997 in a mountain accident while monitoring ibexes. We want to dedicate this work to his memory. 

intermediate between $C$. caucasica and C. pyrenaica appeared, the last becoming clearly differentiated after the Würm glaciation, over 15000 years ago, in the Pyrenean Massif (Crampe, 1990; Crégut-Bonnoure, 1992; Crampe \& Cregut-Bonnoure, 1994). However, another hypothesis considers C. pyrenaica to be derived from an Alpine Ibex (C. ibex) type, which ranged in the Pyrenees between the Riss-Würm glaciations (Engländer, 1986). Moreover, palaeontological remains indicate the presence of Capra in the Iberian Peninsula since 1000000 years ago (Alados \& Escós, 1996). Fossil remains of C. pyrenaica have been found throughout the whole Iberian Peninsula (Gonzales, 1982). This, together with prehistoric paintings, indicates a wide distribution as well as an abundance of the Spanish Ibex during the Palaeolithic and Neolithic periods (Alados, 1985).

If Spanish Ibex were ever abundant during the Middle Ages, their populations decreased significantly during the last centuries due to great hunting pressure, together with agricultural development and habitat deterioration: it disappeared from the French Pyrenees by the midnineteenth century, and around 1890 Cabrera's subspecies C. pyrenaica lusitanica became extinct from its range in the Portuguese Sierra de Geres and Galicia (Cabrera, 1914; Peña, 1978; Gonzales, 1982; Alados, 1985; Fandos, 1991). At the beginning of the twentieth century the first reserve was created (Ordesa, Spanish Pyrenees, in 1918), and during the 1950s and 1960s a global conservation programme was prompted by establishing a system of national game refuges and reserves, and allowing introductions and reintroductions of ibex stocks. These are well documented by Crampe (1990). Recently various ibex populations, mainly from southern Spain, have suffered sarcoptic mange outbreaks. In certain cases, as occurred in the Sierras de Cazorla, Segura y Las Villas Natural Park, the mortality rate due to Sarcoptes scabiei was over 95\% of the whole population (Fandos, 1991). Moreover, the Pyrenean population (C. pyrenaica pyrenaica) became virtually extinct in January 2000, when the last adult female died.

In the Red Book of the Spanish Vertebrates (Blanco \& González, 1992) the Spanish Ibex is catalogued as a rare species. Recently (Alados, 1997) the distribution and status of each ibex subspecies were addressed, the whole Spanish Ibex population being estimated at nearly 16000 individuals: C. p. pyrenaica was considered as endangered, C. pyrenaica victoriae as rare, and C. pyrenaica hispanica as not-threatened. In this paper we revise the current distribution and trends of the species, as well as the main conservation problems involved.

\section{MATERIALS AND METHODS}

Between May 1992 and September 1998 we conducted a survey on the status of the Spanish Ibex. Our sampling method was based mainly on line transects (Anderson et al., 1979; Burnham, Anderson \& Laake, 1980; Buckland et al., 1993) and fixed points chosen for their good visibility (Nievergelt, 1981; Escós \& Alados, 1988), from where distance to animals was recorded during a fixed time $(1 \mathrm{~h})$. Perpendicular distances were processed by using the DIS TANCE V2.0 program (Laake et al., 1993). Regarding fixed points, we used only two recording zones (Greenwood, 1996), the first one with a radius $(r)$ of $900 \mathrm{~m}$, and the second extending from $r$ to infinity. A total transect length of over $2500 \mathrm{~km}$ was covered, both on foot (982: 39.1\%) and by car (1530: 60.9\%). Sampling was planned and designed for each population, taking into account the potential distribution (the mountain range), local climatology, ibex phenology (e.g. the birth period was avoided because of the difficulty in observing females), seasonal movements, daily activity pattern (Pérez, Granados \& Soriguer, 1994) and preliminary data obtained from pilot transects (Burnham et al., 1980). At low densities, when few observations were made, we used a kilometric abundance index (KAI) (relative density), the number of animals observed per kilometre and hour. Moreover, at 
very low densities we only confirmed presence or absence. When synthesizing the abundance, distribution, trend and status of the Spanish Ibex, we used our own data together with those from official reports (generally based on total counts: properly, censuses) and/or published in scientific journals.

\section{RESULTS AND DISCUSSION}

Figure 1 shows the current range of the Spanish Ibex and also represents the historical distribution of the species at the beginning of the nineteenth century (based on Cabrera, 1911; Fandos, 1989). The current distribution of this ungulate in the Iberian Peninsula can be summarized as follows: C. p. pyrenaica is now extinct in its last location, the Ordesa National Park; C. p. victoriae occupies the north-western part of the Iberian Peninsula; C. p. hispanica is the most abundant subspecies (Fig. 1 and Table 1). Different locations are numbered below, in parentheses, to facilitate their identification in Fig. 1.

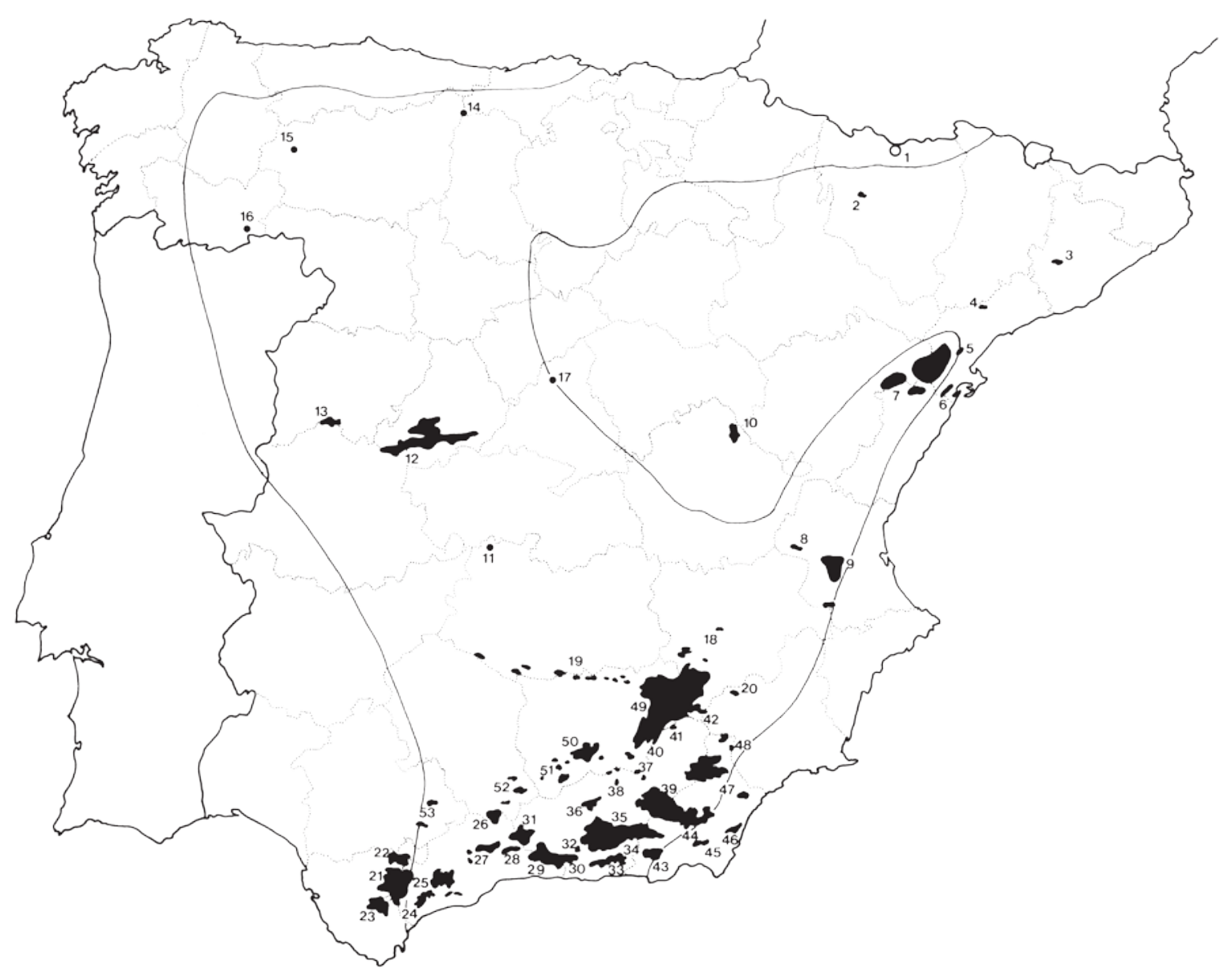

Fig. 1. Current distribution of the Spanish Ibex, Capra pyrenaica. For identification of different nuclei, see the text. Dotted lines delimit boundaries of the provinces and the continuous line indicates the range of the species at the beginning of the nineteenth century (redrawn from Fandos, 1989). 


\section{Pyrenean Massif (1)}

Recently the 'bucardo' (C. p. pyrenaica) population confined in the Arazas Valley, within the Ordesa National Park (Huesca), consisted of an adult female, which was captured, radiocollared and released after collecting blood, skin and faeces samples. Use of the samples taken for cloning purposes is now being considered. Although male specimens from the Tortosa and Beceite national game reserves had been introduced there (García-González \& Herrero, 1999), this population is extinct because the 'last' bucardo died in January 2000 and there has been no evidence of reproduction or hybridization during the last few years. Although abundant in the fourteenth century, a 'slow but continuous persecution' of this population produced its decline and its situation has been critical since the beginning of this century (Cabrera, 1914). At that time, the population was estimated to include about 100 specimens. The last breeding data were reported in 1987 and at the end of the 1980s the population size was estimated at $10 \pm 4$ ibex (García-González, 1990). Different explanations have been considered for the bucardo's decrease: adverse climatic conditions, susceptibility to diseases (e.g. parasitic), undernutrition due to competition with livestock and Chamois (Rupicapra pyrenaica pyrenaica Bonaparte, 1845) (García-González, Escos \& Alados, 1996), among others, could be involved in an extinction vortex. Repopulating the Pyrenean Massif requires reintroduction of individuals coming from other populations. These should be selected according to their genetic characters (Manceau et al., 1999).

\section{Sierra de Guara (2)}

Located in the Huesca province, this harbours several animals that have escaped from the game enclosure of Bastaras, which originally came from Cazorla (Sierras de Cazorla, Segura y Las Villas Natural Park, southern Spain) (C. Gortázar, personal communication). Recently, ibex have been reported on the west side of this mountain range, Mallos de Riglos.

\section{Sierra de Montserrat (3)}

To this site, near Barcelona, between 10 and 20 ibex (from Tortosa y Beceite National Game Reserve) were introduced in 1995 and 1996. This small population seems to be increasing but its potential range is limited.

\section{Sierra del Montsant (4)}

In Tarragona province, the mountain range between Mora and Flix harbours small groups of ibex that have colonized this area from the Sierra de Tortosa. The same occurs in the Sierra de Cardo (5) located in the north of the Sierra de Tortosa (also in the Tarragona province). Some animals have been seen during wild boar battues and the finding of a dead female has been reported. Ibex have also colonized the Sierra del Montsia (6), in the south of the Ebro Delta. These colonization processes seem to be restrained by poaching (J. Miranda, personal communication).

\section{Maestrazgo (7)}

An area overlapping Tarragona, Teruel and Castellón provinces, this comprises the Puertos de Tortosa y Beceite National Game Reserve (30 418 ha), established in 1966 with about 450 ibexes. Since that time, this population has increased to around 700 in 1970, more than 3000 in 1977, 3800 in 1979 and more than 5000 in 1981 (Peña, 1978; Ortuño \& Peña, 1979; Alados, 1985). In our study, we estimated a total of more than 7000 ibex (1000 in Castellón, 1500 in Teruel and 4500 in Tarragona) distributed throughout more than 60000 ha comprising the national game reserve, private game reserves and other wildlife 
Table 1. Catalogue of Spanish Ibex nuclei and numbers, including years and methods of sampling

\begin{tabular}{|c|c|c|c|c|c|c|c|c|}
\hline Denomination & $\begin{array}{c}\text { Year of } \\
\text { introduction }\end{array}$ & $\begin{array}{l}\text { Year and method } \\
\text { of sampling }\end{array}$ & $\begin{array}{c}\text { Effort } \\
\left(\mathrm{km} / \mathrm{km}^{2}\right)\end{array}$ & $\begin{array}{c}\text { Number of ibex } \\
\text { observed }\end{array}$ & $\begin{array}{l}\text { Presence } \\
\text { confirmed }\end{array}$ & $\begin{array}{c}\text { Relative } \\
\text { density (KAI) }\end{array}$ & $\begin{array}{l}\text { Mean density } \\
\left(\text { ibex } / \mathrm{km}^{2}\right)\end{array}$ & $\begin{array}{l}\text { Estimated } \\
\text { size }\end{array}$ \\
\hline 1. Pyrenean Massif & & 1997 & 130 & 1 & + & & & $1-2$ \\
\hline 2. Sierra de Guara & 1980 & & & & + & & & \\
\hline 3. Sierra de Montserrat & 1995-96 & & & & & & & $10-20$ \\
\hline 4. Sierra del Montsant & & ?? & & Small groups & + & & & \\
\hline 5. Sierra de Cardo & & ?? & & Small groups & + & & & \\
\hline 6. Sierra del Montsia & & ?? & & Small groups & + & & & \\
\hline 7. Maestrazgo & 1966 & 1995 & 272 & & & & & 7000 \\
\hline 8. Sierra de Martés & & & & & & & & 400 \\
\hline 9. Muela de Cortes & 1973 & 1995 (LT - FP) & 19 & 32 & & & & 1500 \\
\hline 10. Serranía Cuenca & 1964 & $1992(\mathrm{LT}-\mathrm{FP})$ & 32 & 61 & & & & 550 \\
\hline 11. Cabañeros NP & $<1995$ & 1999 (TC) & & & & & & $15-20$ \\
\hline 12. Gredos & & 1993 (LT) & 104 & 320 & & & $>15$ & 8000 \\
\hline 13. Batuecas NGR & 1974 & 1997 (TC) & 260 & 760 & & & & 900 \\
\hline 14. Riaño & 1991 & & & & & & & 350 \\
\hline 15. Ancares & 1999 & & & & & & & 9 \\
\hline 16. Invernadeiro & 1992 & & & & & & & 60 \\
\hline 17. Pedriza, Soto del Real & 1990 & & & & & & & 250 \\
\hline 18. Alcaraz mountain range & & 1992 (LT) & 22 & 53 & & & & 800 \\
\hline 19. Sierra Madrona-Sierra Morena & & & & & & & & 2600 \\
\hline 20. Sierras Moratalla-Caravaca & 1990 & 1997 (LT - FP) & 200 & 47 & + & & & \\
\hline 21. Sierra de Grazalema NP & & $1998(\mathrm{LT})$ & 19 & 90 & & & $4.4-6.0$ & 1600 \\
\hline 22. Sierra de Líjar & & $1998(\mathrm{LT})$ & 12.7 & 36 & & 2.83 & & 100 \\
\hline 23. Sierra del Aljibe & & & & & + & & & \\
\hline 24. Sierra Bermeja & & 1997 (LT) & 14 & 18 & & & $0.7-3.2$ & 300 \\
\hline 25. Sierra de las Nieves NP & & $1997(\mathrm{LT})$ & 65.6 & 122 & & & $2.3-3.4$ & 1500 \\
\hline 26. Sierras Arcas-Pedroso & & 1995 (LT) & & & + & & & \\
\hline 27. Sierras Sur Antequera & & $1996(\mathrm{LT})$ & 22.9 & 25 & & & $1.2-4.1$ & 2000 \\
\hline 28. Sierra de Alfarnate & & & & & + & & & \\
\hline
\end{tabular}


29. Tejeda-Almijara NGR

30. La Resinera

31. Sierra de Loja

32. Sierra de Guájares-Albuñuelas

33. Sierra de Lújar

34. Contraviesa

35. Sierra Nevada NP

36. Sierras de Huétor NP

37. Depresión Guadix

38. El Mencal

39. Sierra de Baza NP

40. Sierra de Castril NP

41. Sierra de la Sagra

42. Sierras de Lobos y Montilla

43. Sierra de Gádor

44. Sierra Filabres

45. Sierra Alhamilla

46. Sierra Cabrera

47. Sierra Estancias

48. Sierra María NP

49. Sierras de Cazorla, Segura y Las Villas NP

50. Sierra Mágina NP

51. Subbético jiennense

52. Sierras Horconera y Albayate

53. Sierra Tablón y Montes de Osuna
1997 (LT)

1997 (LT)

1997 (LT)

1996 (LT)

1997 (LT)

1997 (LT)

1998 (LT)

1998 (LT)

1996 (LT)

1996 (LT)

1996 (LT)

1996 (LT)

1996 (LT)

1996 (LT)

1997 (LT)

1996 (LT)

1996 (LT)

1996 (LT)

1996 (LT)

1996 (LT)

1998 (LT)

1996 (LT)

1996 (LT)

1996 (LT)

1996 (LT)

\section{5}

35

29

20.5

43

44

84.5

45

25

5

100

28

4.8

8.6

8.6
91

140

40

40

18

80

35

98.9

105

106

10
4.1-6.6

$0.3-1.9$

1500

1.17

0.29

0.33

0.23

500

85

300

500

6.5-8.2 14000

3.0-5.5 900

$0.80 \quad 100$

$0.40 \quad 20$

0.12

200

0.8-1.5

600

0.05

75

70-80

$1.0-1.7$

1300

0.33

LT, line transects; FP, fixed points; TC, total count; NGR, national game reserve; NP, natural park. 
areas, such as the Sierra de Turmell (Castellón province) and Órganos de Montoro, Río Guadalope (Teruel province).

\section{Sierra de Martés (8)}

In Valencia province, this is very close to the Muela de Cortes mountain range and the two areas are connected to each other. Several hundred ibex occur within a game reserve (J.M. Theureau, personal communication).

\section{Muela de Cortes (9)}

Located in Valencia province, this mountain range includes a national refuge (36 009 ha) created in 1973 that included a small remnant population, reinforced with 57 ibex from Cazorla. At present this nucleus consists of over 1500 ibex restricted to the reserve area, its number and spatial range being limited by an increasing Mouflon (Ovis orientalis Gmelin 1774) population.

\section{Serranía de Cuenca (10)}

Here, the Hosquillo National Game Reserve was established with animals from the Cazorla mountain range. This population, consisting of about 500 ibex distributed throughout 25000 ha, is expanding its range to the north: several ibex have been observed in Guadalajara province.

\section{Cabañeros National Park (11)}

Within this park, in the west of Ciudad Real province, there are 15-20 ibex located in approximately 6000 ha (Sierra de Las Parrillas, Chorreras de Muelas y Cigüiñuelas) (National Park staff, personal communication). Ibex were introduced here before 1995.

\section{Gredos mountain range (12)}

This is located between Castilla-León and Extremadura and has been a national game reserve (27 222 ha) since 1976. Here, a small population of C. p. victoriae in 1905 (about 10 animals) grew to almost 4000 ibex within the reserve by 1976 (Ortuño \& Peña, 1979). In 1993 we estimated there were about 8000 ibex distributed throughout the national game reserve and private reserves, with a mean density of more than $15 / \mathrm{km}^{2}$. This population seems to have shown a small decrease in the last few decades, as Peña (1978) reported the existence of more than 9000 animals in the whole Gredos mountain range in 1977.

\section{Batuecas (13)}

This reserve, located in Salamanca province, holds about 900 ibex (C. p. victoriae, from Gredos) distributed throughout a 26 000-ha effective area. This population is increasing, from 200 specimens at the beginning of the 1980s to more than 500 in 1988 (De la Peña, 1982).

\section{Riaño (14)}

In León province there is a game enclosure with about 200 ibex. These came from Gredos and Batuecas and were released between 1991 and 1997. Today these animals share the space with Chamois. In 1998 between 10 and 20 ibex from this enclosure were released into the wild in surrounding areas (Posada de Valdeón and Portilla de la Reina) where both the Wolf (Canis lupus Linné 1758) and Brown Bear (Ursus arctos Linné 1758) are present (authors' own data; J.C. Peral and J. Seijas, personal communication). 


\section{Ancares (15)}

In the north-west tip of the León province, nine ibex from Riaño were released in this mountain range during spring 1999, with another release in the autumn (J.C. Peral, personal communication).

\section{Invernadeiro (16)}

The Campobecerros reserve (or enclosure) is located in the Orense province. There, nearly 30 ibexes from Batuecas were introduced in 1992. The size of this group is now about 60 animals (authors' own data; J. Losa, personal communication).

\section{Pedriza, Soto del Real (17)}

In Madrid province, near the Sierra de Navacerrada, there are about 300 ibex resulting from an introduction made in 1990 with 50 animals from Gredos and Batuecas (C. p. victoriae).

\section{Alcaraz mountain range (18)}

At the north of the Sierras de Cazorla, Segura y Las Villas Natural Park, in the Albacete province, this range includes about 300 ibex in a 9000-ha controlled area, together with 500 animals distributed throughout adjacent mountains. It is an expanding population.

\section{Sierra Madrona - Sierra Morena (19)}

These mountain ranges, in Ciudad Real and Jaén provinces, comprise very fragmented nuclei, mainly located within private game reserves after previous introductions. Those located in the Garganta private reserve may have their origin in a relict natural nucleus. We have estimated the presence of over 1500 animals in Ciudad Real province and 1100 ibex in the Sierra Morena mountain range of Jaén province.

\section{Sierra de Moratalla - Sierra de Caravaca (20)}

Located in Murcia province, the presence of the Spanish Ibex in these mountain ranges was confirmed in 1990, during surveys of Barbary Sheep (Ammotragus lervia Pallas 1777). The ibex were affected by sarcoptic mange.

\section{Andalucía (21-53)}

This is, probably, the best known region for the Spanish Ibex. Granados et al. (1998) reported up to 34 nuclei with a total number of individuals of around 30000 , and their current densities are included in Table 1. These are distributed throughout $9900 \mathrm{~km}^{2}$. Several populations show high densities: Sierra de Grazalema Natural Park, Cádiz province (4.4-6.0/km²); Sierra Tejeda, Málaga province (4.1-6.6/ $\left.\mathrm{km}^{2}\right)$; and Sierra Nevada Natural Park, Granada and Almería provinces $\left(6.5-8.2 / \mathrm{km}^{2}\right)$. With a total size of nearly 14000 , this is considered to be the largest population in the Iberian Peninsula. It has been increasing, especially after the creation of the national game reserve in 1966 (Pérez et al., 1994).

The ibex population of the Sierras de Cazorla, Segura y Las Villas Natural Park (Jaén province), suffered an outbreak of sarcoptic mange in 1997, producing a mortality rate greater than 95-99\%. Four years later only 150 ibex were known to have survived the epizooty (Fandos, 1991). In 1998 we estimated a population size of about 1200 animals, distributed at low densities: $1.1-1.5 / \mathrm{km}^{2}$. In these mountain ranges, the disease continues to affect not only this species but also other sympatric wild ungulates: Red Deer (Cervus elaphus Linné 1758), Fallow Deer (Dama dama Linné 1758) and Mouflon. Fandos (1991) considered that this population has passed three recent bottlenecks: the first in 1911, the second in about 
1939, and the last one in 1988 (this due to the scabies epizooty). Moreover, scabies has reached other ibex populations: Sierra Mágina Natural Park (Jaén province) (Palomares \& Ruiz, 1993); Sierras de Castril Natural Park, Sierra de Loja, Sierra de la Sagra, Sierra del Mencal, Sierra de Almijara, Sierras de Huétor Natural Park and Sierra Nevada Natural Park (Granada and Almería); and Sierra de las Nieves Natural Park (Málaga province). Nowadays this problem also affects other ungulate species outside Andalucía, e.g. Barbary Sheep in Sierra Espuña Natural Park (Murcia) and the Cantabrian Chamois Rupicapra pyrenaica parva (Cabrera, 1911) (Asturias).

When comparing our data with those previously reported in the literature (Peña, 1978; Alados, 1985; Fandos, 1989, 1991), we observed an increase in both the total numbers and the number of nuclei. This reflects not only a natural and unnatural expansion of the species, but also an increase in the sampling effort and the studied area. Our interpretation of the review by Alados (1997) in the early to mid-1990s, who estimated the overall Spanish population to be between 11000 and 12000 ibex, is that her work was based only on bibliographical, instead of field, data.

The Spanish Ibex was also introduced in Argentina (Olrog \& Lucero, 1981) but little is known about the current status and distribution of the species in that country. Currently, a project on determining the habitat suitability to reintroduce the species in the Sierra de Geres (north-west Portugal) is being evaluated. Another project for reintroducing the Spanish Ibex in the French Pyrenees was initiated in 1991 by the staff of the Parc National des Pyrénées in collaboration with the Office National de la Chasse. The first part of this study consisted of determining potential suitable sites for reintroduction. The second goal of this project was to make a phylogenetic study of the Iberian and Alpine ibex populations to select the most appropriate source of individuals. This study has been supported by a Life programme: Restauration de la grande faune pyrénéene.

\section{FACTORS AFFECTING THE SPANISH IBEX CONSERVATION}

\section{Habitat alteration and fragmentation}

Agro-sylvicultural activities, urbanization, infrastructure (e.g. highways) and fire, among other human activities, may be considered as the main factors threatening ibex conservation. We must take into account that different protected areas (natural parks) harbouring ibex populations (e.g. Sierras de Cazorla, Segura y Las Villas, Sierra Mágina and Sierra Nevada) have also more or less threatened floras, characterized by a high number of endemic taxa. The continuous alteration and destruction of mountain habitats influences the ibex distribution, fragmenting it into metapopulations. This is our current interpretation of the spatial distribution of the ibex, which needs to be supported by genetic analyses and by specific studies on ibex movements between close mountain ranges. These metapopulations need to be demographically characterized, by establishing local extinction and replacement rates.

\section{Inadequate management of ibex populations}

Management carried out during the last few decades did not take into account the growth rate of each population and, generally, has been orientated to trophy harvest, leading in most cases to densities over the species' carrying capacity, as well as populations with a distorted sex ratio and/or age structure. Moreover, the systematic harvest of the best trophies is considered to be a major factor of genetic impoverishment (Hartl, 1992). On the other hand, as poaching for trophy heads presumably also concentrates on the oldest males, it is quite difficult to quantify and evaluate the overall effect. 


\section{Genetic background}

Because of their high rate of change in peripheral regions, sequences of some mitochondrial genes (mtDNA), such as cytochrome b (cyt b) or the main non-coding control region (CR), are widely used in population and evolutionary genetics of mammals. Mitochondrial DNA coding genes and, in particular, the sequence of cyt b have proved useful for resolving phylogenetic patterns among artiodactyls within evolutionary time frames less than 20 million years (Randi et al., 1998). The level of variation detected in the mtDNA (cyt b or CR) of $C$. pyrenaica reinforces the view that the initial founding population consisted of a small number of founders (possibly over several dozens of individuals). The actual distribution of genetically defined subpopulations may be explained as a local founder effect, with local haplotype evolution and partial extinction of a high proportion of the effective population in recent times. The study of Manceau et al. (1999) focused on finding the most appropriate source of individuals to restore the Pyrenean ibex population. After studying the sequence variability of a proportion of the mitochondrial CR and cyt b, they found a relatively high level of divergence between the Alpine Ibex (C. ibex) and the Spanish Ibex, comparable to the level of divergence between the Pyrenean and other Spanish haplotypes. These authors considered the Sierra Nevada population as the most diverse. On the other hand, the groups (evolutionary significant units; ESU) supported by high bootstrap values were not all congruent with those based on morphological taxonomy (Cabrera, 1911). Another study (Sánchez \& Jiménez, 1998) carried out on 57 samples of C. pyrenaica, from eight populations, concluded that only 10 of the 13 microsatellites could be considered as informative. These authors considered the population from Tortosa-Beceite (7) as the most variable and therefore the most appropriate to reinforce the Pyrenean population. Although genetic information derived from both studies is fragmentary and refers only to small samples coming from a few nuclei or populations, results are quite similar, and the phylogenetic trees derived from the two data sets are, in the main, comparable.

In a recent genetic analysis carried out in the context of the Andalusian populations of C. pyrenaica (authors' unpublished data), we studied the variability of a large fragment of cyt b (910 base pairs) within a sample of 276 specimens and detected the presence of at least 10 different mitochondrial haplotypes, distributed in two clearly separated populations. The Sierra Nevada population includes seven of the 10 haplotypes characterized for the Andalusian ibex populations. This might indicate that this population has conserved a relatively high effective population over time or, in other words, it has not been involved in drastic bottleneck processes. The populations distributed in south-west Andalucía (mainly in Málaga and Cádiz provinces) show only two haplotypes, which may be interpreted as a consequence of considerable stress during recent history and a depletion in the number of ancestral haplotypes in these populations. In conclusion, we hypothesize the existence of at least three ESUs (data from C. p. victoriae are not available), located in Pyrenees, Gredos and surrounding areas, and the south-eastern Iberian Peninsula.

In the future, the main goal should be to determine the structure of populations on the basis of genetic markers variable enough to detect differences between regional samples (e.g. an extensive study of microsatellite loci). In this way we can document changes in genetic variability due to translocations and founder events in peripheral ibex populations.

In Spain overall, several regional populations composed of a series of partially independent local populations could be considered. Each population seems to contain unique portions of the total genetic variation. Thus, we recommend that they be treated as separate management units. Translocations may be necessary in re-establishing certain 
populations. In these cases, the source of donor individuals must be carefully evaluated, especially if preservation of current genetic structure is considered to be a conservation goal.

\section{Competition with domestic and wild ungulates}

Much of the range of the Spanish Ibex is shared, specially in summer months when exploiting the summer high mountain pastures, with sheep, domestic goats, cattle and horses. This leads to interspecific competition (Fandos, 1991; Martínez, 1992) and overgrazing, which may become specially important in dry years. In addition, the introduction of alochtonous wild ungulate species in areas occupied by the ibex (e.g. Fallow Deer and Mouflon in the Sierras de Cazorla, Segura y Las Villas Natural Park) not only increases the grazing pressure, but also the potential risk of transmission of both native and exotic diseases (Fandos \& Reig, 1992).

\section{Human disturbance}

Tourism and mountain sports (trekking, rock-climbing, cycling, bikes, cars and skiing) and, eventually, field scientific research, among other 'non-consumptive' activities, often exclude ibex from regular and favourable feeding habitats (Alados, 1985).

\section{Diseases}

Both infectious and non-infectious diseases, together with predation, are important factors regulating the demographic trend of wild populations. Over 60 species of endo- and ectoparasites have been reported from C. pyrenaica (Rossi, Marco \& Meneguz, 1994; Pérez et al., 1996a, b; Lavín et al., 1997). Sarcoptic mange or scabies, produced by the astigmatid mite Sarcoptes scabiei, has become one of the most important factors increasing the mortality rate in populations, and has international repercussions on wild mammals, especially mountain ungulates (Kutzer, 1966; Fain, 1978; Miller, 1985; Rossi et al., 1995; Pérez et al., 1997; Fernández et al., 1997). Infecto-contagious diseases have been also studied in the Spanish Ibex. León et al. (1994) reported prevalence of borreliosis (20.5\%), chlamydiosis (12.0\%), pasteurellosis (5.8\%) and brucellosis (2.9\%) in the ibex from Sierra de Las Nieves Natural Park. In the Sierras de Cazorla, Segura y Las Villas Natural Park, within the period 1982$84,30 \%$ of females surveyed were affected by brucellosis, and tuberculosis was diagnosed in $18 \%$ of samples, especially in males (Fandos, 1991). A general feature of many of these agents is their lack of host-specificity, being able to infect both the Spanish Ibex and other wild and domestic ungulates, among other mammals. Therefore, at high host densities, the availability of habitat for both micro- and macroparasites increases, as does the risk of epizootics.

In spite of the estimated current number of ibex and the globally upward trend, because of the influence of the above-mentioned factors, the fragmentation level and overall size of the range of the species, we consider that the current status of $C$. pyrenaica, according to the criteria given by the IUCN Caprinae Specialist Group (Shackleton, 1997), must be vulnerable. This is especially true for the population located in the Gredos mountain range, due to its high density. The so-called C. p. pyrenaica (bucardo) population is virtually extinct, and the southern populations (included within C. p. hispanica) must be considered in general terms at a lower risk, but needing specific habitat conservation programmes and adequate management plans. Eventually, some of these populations may suffer severe fluctuations due to epizootic processes, and reach the status of vulnerable. 


\section{ACKNOWLEDGEMENTS}

The authors wish to thank Mr M. Moreno, Mrs M.C. Pérez, Mr C. Franco, Mr E. Serrano, Mr J.M. Gil, Mr F. Gómez, Mr J. García, Mr J. Navarro, Mr E. García, Mr M. Alguacil, the gamekeepers, specially Mr A. Rodríguez, and Dr J.R. Delibes for their collaboration in field samplings. Mr J. Miranda, Mr J.C. Peral and Mr J. Seijas provided valuable data. This work has been largely supported by the Junta de Andalucía, project: 'Seguimiento y control de la sarna sarcóptica en las poblaciones de cabra montés (C. p. hispanica) existentes en Andalucía', Convenio Universidad de Jaén - Consejería de Medio Ambiente. Comments from D. W. Yalden, S. Lovari and an anonymous referee contributed to improve substantially the manuscript.

\section{REFERENCES}

Alados, C.L. (1985) Distribution and status of the Spanish Ibex (Capra pyrenaica). In: The Biology and Management of Mountain Ungulates (Ed. by S. Lovari), pp. 204-211. Croom-Helm, Beckenham, UK.

Alados, C.L. (1997) Status and distribution of Caprinae by region. Spain. In: Wild Sheep and Goats and Their Relatives (Ed. by D.M. Shackleton), pp. 125-130. IUCN, Cambridge, UK.

Alados, C.L. \& Escós, J. (1996) Ecología y comportamiento de la cabra montés. Consideraciones para su gestión. Museo Nacional de Ciencias Naturales (CSIC), Madrid, Spain.

Anderson, D.R., Laake, J.L., Cran, B.R. \& Burnham, K.P. (1979) Guidelines for line transect sampling of biological populations. Journal of Wildlife Management, 43, 70-78.

Blanco, J.C. \& González, J.L. (1992) Libro rojo de los vertebrados de España. ICONA, Madrid, Spain.

Buckland, S.T., Anderson, D.R., Burnham, K.P. \& Laake, J.L. (1993) Distance Sampling Estimating Abundance of Biological Populations. Chapman \& Hall, London, UK.

Burnham, K.P., Anderson, D.R. \& Laake, J.L. (1980) Estimation of density from line transect sampling of biological populations. Wildlife Monographs, 72, 1-202.

Cabrera, A. (1911) The subspecies of the Spanish ibex. Proceedings of the Zoological Society of London, 1911, 963-967.

Cabrera, A. (1914) Fauna Ibérica Mamíferos. Hipódromo, Madrid, Spain.

Clouet, M. (1979) Note sur la systématique du bouquetin d’Espagne. Bulletin de la Societé d'Histoire Naturelle Toulouse, 115, 269-277.

Corbet, G.B. (1978) The Mammals of the Palaearctic Region: A Taxonomic Review. British Museum (Natural History)-Cornell University Press, London and Ithaca.

Couturier, M. (1962) Le bouquetin des Alpes (Capra aegagrus ibex L.). Grenoble, France.

Crampe, J.P. (1990) Le bouquetin iberique. Elements pour une reintroduction au versant nord des Pyrénées occidentales. Documents Scientifiques Du Parc National Des Pyrénées, 26, 187.

Crampe, J.P. \& Cregut-Bonnoure, E. (1994) Le massif des Pyrénées, habitat naturel du bouquetin iberique (Capra pyrenaica Schinz, 1838). Evolution temporo-spatiale de l'espece de la prehistoire a nos jours. IBEX Journal of Mountain Ecology, Volume speciale, 39-48.

Crégut-Bonnoure, E. (1992) Pleistocene tahrs, ibexes and chamois of France. In: Ongulés/Ungulates 91 (Ed. by F. Spitz, G. Janeau, G. Gonzalez \& S. Aulagnier), pp. 49-56. SFEPM-IRGM, Paris-Tolouse, France .

De la Peña, J. (1982) Población española de Capra pyrenaica en 1982. Council International de la Chasse, Pontresina, Switzerland.

Engländer, H. (1986) Capra pyrenaica Schinz, 1838 - Spanischer Steinbock, Iberiensteinbock. In: Handbuch der Säugetiere Europas, Vol 2/II (Ed. by J. Niethammer \& F. Krapp), pp. 405-422. AULA-Verlag, Wiesbaden, Germany.

Escós, J. \& Alados, C.L. (1988) Estimating mountain ungulate density in Sierras de Cazorla y Segura. Mammalia, 52, 425-428.

Fain, A. (1978) Epidemiological problems of scabies. International Journal of Dermatology, 17, 20 -31.

Fandos, P. (1989) Distribución de la cabra montés en España. Quercus, 36, 20-26.

Fandos, P. (1991) La cabra montés Capra pyrenaica en el Parque Natural de las Sierras de Cazorla, Segura y Las Villas. ICONA-CSIC, Madrid, Spain.

Fandos, P. \& Medem, R. (1994) Los ungulados de montaña. In: Argali. Cacerías de alta montaña (Ed. by R. Medem) pp. 271-275. Agualarga Editores, Madrid, Spain.

Fandos, P. \& Reig, S. (1992) Problems associated with mouflon and barbary sheep introductions in Spain. In: Global Trends in Wildlife Management (Ed. by B. Bobek, K. Pierzanowski \& W. Regelin), pp. 139-140. Swiat Press, Krakow-Warszawa, Poland. 
Fernández, J., Gómez, S., Ballesteros, F., Quirós, P., Benito, J.L., Feliu, C. \& Nieto, J.M. (1997) Epizootiology of sarcoptic mange in a population of cantabrian chamois (Rupicapra pyrenaica parva) in Northwestern Spain. Veterinary Parasitology, 73, 163-171.

García-González, R. (1990) Informe final. Proyecto 'Inventario de la población española de bucardo'. ICONA, Madrid, Spain.

García-González, R. \& Herrero, J. (1999) El bucardo de los Pirineos: historia de una extinción. Galemys, 11, $17-26$.

García-González, R., Escós, J. \& Alados, C.L. (1996) Una población en peligro: el bucardo. In: Ecología Y Comportamiento de la Cabra Montés Consideraciones Para Su Gestión (Ed. by C.L. Alados \& J. Escós), pp. 105-120. Museo Nacional de Ciencias Naturales, Madrid, Spain.

Gonzales, G. (1982) Eco-ethologie des ongulés de montagne, aproche evolutive. Acta Biologica Montana, 1, $121-152$.

Granados, J.E., Chirosa, M., Pérez, M.C., Pérez, J.M., Ruiz, I., Soriguer, R.C. \& Fandos, P. (1998) Distribution and status of the Spanish ibex Capra pyrenaica in Andalusia, southern Spain. In: Proceedings of the 2nd World Conference Mountain Ungulates (Ed by V. Peracino, S. Lovari \& B. Bassano), pp. 129-133. Parco Nationale del Grau Paradiso; Torino, Italy. pp. 129-133.

Granados, J.E., Pérez, J.M., Soriguer, R.C., Fandos, P. \& Ruiz, I. (1997) On the biometry of the Spanish ibex, Capra pyrenaica, from Sierra Nevada (southern Spain). Folia Zoologica, 46, 9-14.

Greenwood, J.J.D. (1996) Basic techniques. In: Ecological Census Techniques (Ed. by W.J. Sutherland), pp. 11-110. Cambridge University Press, Cambridge, UK.

Hartl, G.B. (1992) Genetic variation in ungulates and its phylogenetic, ecological and anthropogenic determinants. In: Ongulés/Ungulates 91 (Ed. by F. Spitz, G. Janeau, G. Gonzalez \& S. Aulagnier), pp. 1-4. SFEPMIRGM, Paris-Tolouse, France.

Kutzer, E. (1966) Zur epidemiologie der Sarcoptesräude. Angewandte Parasitologie, 7, 241-248.

Laake, J.L., Buckland, S.T., Anderson, D.R. \& Burnham, K.P. (1993) Distance User's guide, Version 2.0. Colorado State University, Fort Collins, CO.

Lavín, S., Marco, I., Rossi, L., Meneguz, P.G. \& Viñas, L. (1997) Haemonchosis in Spanish ibex. Journal of Wildlife Diseases, 33, 656-659.

León, L., De Meneghi, D., Meneguz, P.G., Rosati, S. \& Rossi, L. (1994) Investigaciones serológicas sobre enfermedades infecciosas de la cabra montés (Capra pyrenaica) en el Parque Natural Sierra de Las Nieves, Ronda, Málaga (E): resultados y consideraciones preliminares. In: Actas del Congreso Internacional del género Capra en Europa, Ronda, (Ed. by M.A. Catalino, J. Zulueta, P.G. Meneguz \& L. Rossi), pp. 219-222. Junta Rectora del Parque Natural de la Sierra de las Nieves; Malaga, Spain.

Manceau, V., Crampe, J.P., Boursot, P. \& Taberlet, P. (1999) Identification of evolutionary significant units in the Spanish wild goat, Capra pyrenaica (Mammalia, Artiodactyla). Animal Conservation, 2, 3339.

Martínez, T. (1992) Estrategia alimentaria de la cabra montés (Capra pyrenaica) y sus relaciones tróficas con los ungulados silvestres y domésticos en $S^{a}$ Nevada, $S^{a}$ de Gredos y $S^{a}$ de Cazorla. PhD Thesis. Universidad Complutense, Madrid, Spain.

Miller, C. (1985) The impact of mange on chamois in Bavaria. In: The Biology and Management of Mountain Ungulates (Ed. by S. Lovari), pp. 243-249. Croom-Helm, Beckenham, UK.

Nievergelt, B. (1981) Ibexes in an African Environment. Springer-Verlag, Berlin, Germany.

Olrog, C.C. \& Lucero, M.M. (1981) Guía de los mamíferos argentinos. Ministerio de Cultura y Educación, Tucumán, Argentina.

Ortuño, F. \& Peña, J. (1979) Reservas y cotos nacionales de caza. INCAFO, Madrid, UK.

Palomares, F. \& Ruiz, I. (1993) Status und Aussichten für den Schutz der Population des Spanischen Steinbocks (Capra pyrenaica Schinz, 1838) im Sierra Mágina Naturpark in Spanien. Zeitscrift für Jagdwissenschaft, 39, 87-94.

Peña, J. (1978) La cabra montés en España. International Game Congress, Switzerland.

Pérez, J.M., Granados, J.E., Gómez, F., Pérez, M.C., Ruiz, I. \& Soriguer, R.C. (1996a) Las Parasitosis de la Cabra Montés de Sierra Nevada (Granada). In: $1^{a}$ Conferencia Internacional sobre Sierra Nevada. Conservación y Desarrollo Sostenible, Vol III (Ed. by J. Chacón \& J.L. Rosúa), pp. 31-45. Univ. Granada, Sierra Nevada 96, Consejerío de Medio Ambiente \& Unesco; Madrid, Spain.

Pérez, J.M., Granados, J.E. \& Soriguer, R.C. (1994) Population dynamic of the Spanish ibex Capra pyrenaica in Sierra Nevada Natural Park (southern Spain). Acta Theriologica, 39, 289-294.

Pérez, J.M., Granados, J.E., Soriguer, R.C. \& Ruiz, I. (1996b) Prevalence and seasonality of Oestrus caucasicus Grunin, 1948 (Diptera: Oestridae) parasitizing the Spanish ibex, Capra pyrenaica (Mammalia: Artiodactyla). Journal of Parasitology, 82, 233-236.

Pérez, J.M., Ruiz, I., Granados, J.E., Soriguer, R.C. \& Fandos, P. (1997) The dynamics of sarcoptic mange in 
the ibex population of Sierra Nevada in Spain - influence of climatic factors. Journal of Wildlife Research, 2, 86-89.

Randi, E., Mucci, N., Pierpaoli, M. \& Douzery, A. (1998) New phylogenetic perspectives on the Cervidae (Artiodactyla) are provided by the mitochondrial cytochrome b gene. Proceedings of the Royal Society of London B, 26, 793-801.

Rossi, L., Marco, I. \& Meneguz, P.G. (1994) Nematodes of the digestive tract of Capra pyrenaica: preliminary contribution. In: Actas del Congreso Internacional del género Capra en Europa, Ronda, (Ed. by M.A. Catalino, J. Zulueta, P.G. Menegue \& L. Rossi), pp. 249-251. Junta Rectora del Parque Natural de la Sierra de las Nieves; Málaga, Spain.

Rossi, L., Meneguz, P.G., de Martin, P. \& Rodolfi, M. (1995) The epizootiology of sarcoptic mange in chamois, Rupicapra rupicapra, from the Italian eastern Alps. Parassitologia, 37, 233-240.

Sánchez, A. \& Jiménez, N. (1998) Plan de recuperación del bucardo (Capra pyrenaica pyrenaica). Estudio genético molecular de las poblaciones de cabra montés de la Península Ibérica. Scientific Report. Universitat Autònoma de Barcelona, Barcelona, Spain.

Schaller, G. (1977) Mountain Monarchs. University of Chicago Press, Chicago, IL.

Shackleton, D.M. (1997) Wild Sheep and Goats and their Relatives. IUCN, Cambridge, UK.

Submitted 12 January 2000; returned for revision 21 August 2000; revision accepted 24 October 2000 